\title{
Calcium-Induced Activity and Folding of a Repeat in Toxin Lipase from Antarctic Pseudomonas fluorescens Strain AMS8
}

\author{
Nur Shidaa Mohd Ali ${ }^{1,2}$, Abu Bakar Salleh ${ }^{1}$, Raja Noor Zaliha Raja Abd Rahman ${ }^{1,3}{ }^{\circledR}$, \\ Thean Chor Leow ${ }^{1,4}$ (I) and Mohd Shukuri Mohamad Ali ${ }^{1,2, *}$
}

1 Enzyme and Microbial Technology Research Center, Faculty of Biotechnology and Biomolecular Sciences, Universiti Putra Malaysia, 43400 Serdang, Selangor, Malaysia; nur_shidaa@yahoo.com (N.S.M.A.); abubakar@upm.edu.my (A.B.S.); rnzaliha@upm.edu.my (R.N.Z.R.A.R.); adamleow@upm.edu.my (T.C.L.)

2 Department of Biochemistry, Faculty of Biotechnology and Biomolecular Sciences, Universiti Putra Malaysia, 43400 Serdang, Selangor, Malaysia

3 Department of Microbiology, Faculty of Biotechnology and Biomolecular Sciences, Universiti Putra Malaysia, 43400 Serdang, Selangor, Malaysia

4 Department of Cell and Molecular Biology, Faculty of Biotechnology and Biomolecular Sciences, Universiti Putra Malaysia, 43400 Serdang, Selangor, Malaysia

* Correspondence: mshukuri@upm.edu.my; Tel.: +60-3-9769-6721

Received: 13 September 2019; Accepted: 30 October 2019; Published: 1 January 2020

check for updates

\begin{abstract}
It is hypothesized that the $\mathrm{Ca}^{2+}$ ions were involved in the activity, folding and stabilization of many protein structures. Many of these proteins contain repeat in toxin (RTX) motifs. AMS8 lipase from Antarctic Pseudomonas fluorescens strain AMS8 was found to have three RTX motifs. So, this research aimed to examine the influence of $\mathrm{Ca}^{2+}$ ion towards the activity and folding of AMS8 lipase through various biophysical characterizations. The results showed that $\mathrm{CaCl}_{2}$ increased lipase activity. The far-UV circular dichroism (CD) and Fourier-transform infrared (FTIR) analysis suggested that the secondary structure content was improved with the addition of $\mathrm{CaCl}_{2}$. Fluorescence spectroscopy analysis showed that the presence of $\mathrm{CaCl}_{2}$ increased protein folding and compactness. Dynamic light scattering (DLS) analysis suggested that AMS8 lipase became aggregated at a high concentration of $\mathrm{CaCl}_{2}$. The binding constant $\left(\mathrm{K}_{\mathrm{d}}\right)$ value from the isothermal titration calorimetry (ITC) analysis proved that the $\mathrm{Ca}^{2+}$ ion was tightly bound to the AMS8 lipase. In conclusion, $\mathrm{Ca}^{2+}$ ions play crucial roles in the activity and folding of the AMS8 lipase. Calcium binding to RTX nonapeptide repeats sequences will induced the formation and folding of the RTX parallel $\beta$-roll motif repeat structure.
\end{abstract}

Keywords: RTX lipase; AMS8 lipase; family I.3; RTX parallel $\beta$-roll motif repeat; $\mathrm{Ca}^{2+}$ ion; calcium binding; folding; activity

Key Contribution: The current research offers a more comprehensive investigation of $\mathrm{Ca}^{2+}$ ion using different biophysical techniques. A significant contribution of $\mathrm{Ca}^{2+}$ ions in maintaining the integrity and functionality of AMS8 lipase was presented.

\section{Introduction}

Repeat in toxin (RTX) proteins represent a broad and diverse family of proteins produced by Gram-negative bacteria. RTX proteins can be divided into several classes including RTX lipases, RTX proteases, RTX cytotoxins and Multifunctional-autoprocessing repeats-in-toxin (MARTX) [1]. RTX proteins exhibit two common characteristics. The first characteristic is the appearance of nonapeptide sequences (GGXGXDXUX) (consisting of glycine (G), aspartate (D), any amino acid (X) 
and a hydrophobic amino acid (U)) at the carboxy terminal. The nonapeptide sequences are responsible for creating specific calcium-binding positions and after calcium binding, the parallel $\beta$-roll motif repeat structure of the RTX was formed [2]. The RTX parallel $\beta$-roll motif repeat structure comprised nonapeptide sequences and $\mathrm{Ca}^{2+}$ ions [3]. The second characteristic is the style of secretion through the type I secretion system (TISS). The RTX parallel $\beta$-roll motif repeat structure was involved in the process of exporting the passenger protein (including RTX proteins) out of the bacterial cell through T1SS [4].

Of note, the RTX parallel $\beta$-roll motif repeat structure has been hypothesized to require $\mathrm{Ca}^{2+}$ ion to exert its biological function and influence in the folding and stabilization of many protein structures [3]. To date, the exact function of the RTX parallel $\beta$-roll motif repeat structure is still poorly understood [1]. So far, it is not understood how the $\mathrm{Ca}^{2+}$ ion induces the folding of the RTX parallel $\beta$-roll motif repeat structure and how it helps to sustain the structural integrity of the whole protein structure. The cases may be linked to the activity, folding and secretion of RTX proteins [5]. However, previous studies have suggested that the RTX parallel $\beta$-roll motif repeat structure is responsible for internal chaperones, enhancers of the secretion process and receptor-binding domains [4].

In 2013, a new RTX lipase from Pseudomonas fluorescence (AMS8 lipase) belonging to the I.3 subfamily was isolated from Antarctic soil (psychrophilic bacteria). The crude enzyme showed maximum activity at $20{ }^{\circ} \mathrm{C}$ [6]. A previous study applied a computational approach (homology modeling) to predict the 3D structure of AMS8 lipase [7]. AMS8 lipase consists of 476 amino acids. The predicted structure of AMS8 lipase obtained from Ali et al. (Supplementary Materials Figure S1) [7] consisted of the catalytic (residue 1-392) and non-catalytic (residue 393-405) domains. The catalytic domain at the $\mathrm{N}$-terminal was rich in $\alpha$-helices $(\alpha 20)$ and the non-catalytic domain was monopolized by $\beta$-strands ( $\beta$ 17). The catalytic domain consisted of an $\alpha / \beta$ hydrolase fold and catalytic triad, which combined Ser ${ }^{207}, \mathrm{Asp}^{255}$ and $\mathrm{His}^{313}$ residues. Commonly, lipase can occur in two conformational categories: active and inactive. The active or inactive conformation states were determined based on the lid conformation, either open or closed. For AMS8 lipase, there are two lid structures covering the catalytic site on the catalytic domain [8].

Based on the predicted structure, AMS8 lipase contains one $\mathrm{Zn}^{2+}$ and six $\mathrm{Ca}^{2+}$ ions. Besides, the predicted model of AMS8 lipase also showed the presence of nonapeptide sequences at the C-terminal. The RTX nonapeptide repeats sequences will form the RTX parallel $\beta$-roll motif repeat structure specifically upon binding with $\mathrm{Ca}^{2+}$ ions [9]. AMS8 lipase consists of three RTX parallel $\beta$-roll motif repeat structures (residue 373-405). These motifs constituted a specific type of $\mathrm{Ca}^{2+}$ ion-binding site that was necessary for the formation of the parallel $\beta$-roll motif repeat structure. $\mathrm{Ca}^{2+}$ ions were crucial in the formation of the RTX parallel $\beta$-roll repeat structure and the presence of $\mathrm{Ca}^{2+}$ ions is also important for both the folding and stability of many protein domains [10]. Besides, metal ions can be a factor in the stabilization and functionality of the protein structure [11].

In the current work, RTX lipase (AMS8 lipase) from Pseudomonas fluorescens strain AMS8 (accession numbers ADM87309) has been studied. Previous homology modeling revealed that the AMS8 lipase predicted structure consists of $\mathrm{Ca}^{2+}$ ions that maybe involved in the functionality/folding of the RTX parallel $\beta$-roll motif repeat structure and also the whole AMS8 lipase structure. Thus, this research aimed to examine the influence of $\mathrm{Ca}^{2+}$ ions in the activity and folding of AMS8 lipase. To further characterize the functionality/folding differences influenced by the binding of $\mathrm{Ca}^{2+}$ ions towards AMS 8 lipase, the physicochemical characteristic of AMS8 lipase was investigated by utilizing biophysical approaches.

\section{Results and Discussion}

\subsection{Calcium-Binding Site and RTX $\beta$-Roll Motif Repeat Structure of the AMS8 Lipase Predicted Model}

In order to further analyze the presence of $\mathrm{Ca}^{2+}$ ions in the AMS8 lipase predicted structure, we used the database to explore the calcium-binding site of each of the $\mathrm{Ca}^{2+}$ ions. The ligplot of the interaction involving the calcium-binding site of analysis from the pictorial database of 3D structures in 
the Protein Data Bank (PDBsum) was visualized using YASARA software [12] Figure 1 shows that the Ca1 was bound with $\operatorname{Asn}^{284}(2.294 \AA)$ and Glu ${ }^{253}$ (2.209 $\AA$ ) (Figure 1b), Ca2 with Asp 283 (2.328 $)$ and

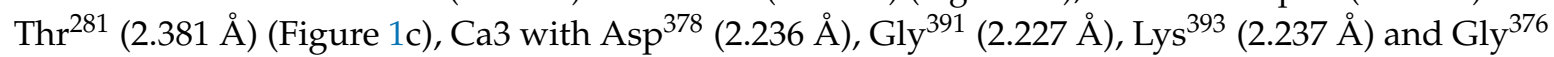
$(2.272 \AA)$ (Figure 1d), Ca4 with $\operatorname{Asp}^{387}(2.270 \AA), \operatorname{Gly}^{383}$ (2.341 $\AA$ ) and $\mathrm{Gly}^{385}$ (2.310 A) (Figure 1e),

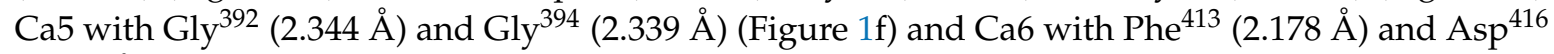
(1.523 $\AA$ ) (Figure $1 g$ ). Both Ca1 and Ca2 were located at the catalytic domain, while Ca3, Ca4 and Ca5 were located at the RTX parallel $\beta$-roll motif repeat structure in the non-catalytic domain and Ca6 was also located at the non-catalytic domain of the AMS8 lipase structure. Figure 2 shows the $\mathrm{Ca}^{2+}$ ion involved in the formation of the RTX parallel $\beta$-roll motif repeat structure.

The demand for $\mathrm{Ca}^{2+}$ ions in the RTX parallel $\beta$-roll motif repeat structure formation was reported for Escherichia coli a-hemolysin [9] and Bordetella pertussis CyaA [13]. The binding of $\mathrm{Ca}^{2+}$ ions to the RTX parallel $\beta$-roll motif repeat structure only occurs during secretion (outside the bacterial cell), since the concentration of $\mathrm{Ca}^{2+}$ ions inside the bacterial cell was low (0-100 nM) [14]. This condition makes the RTX parallel $\beta$-roll motif repeat structure remain floppy/unfolded before being secreted out of the bacterial cell through the TISS $[15,16]$. Calcium binding to the RTX parallel $\beta$-roll motif repeat structure in the $C$-terminal will assist the functional/folding of secreted RTX proteins outside the bacterial cell [17-19]. Besides, the presence of $\mathrm{Ca}^{2+}$ ions is also compatible with both the stability and folding of many protein domains [10].

Binding and release of $\mathrm{Ca}^{2+}$ ions change the structural properties of the involved calcium-binding proteins such that they will switch their state during interaction with other proteins or during enzymatic reaction [20]. The parts of the consecutive turns and $\beta$-strands form a right-hand parallel $\beta$-helix that is stabilized by the binding of $\mathrm{Ca}^{2+}$ ions. Meanwhile, without $\mathrm{Ca}^{2+}$ ions, these RTX parallel $\beta$-roll motif repeat structures appear to be mostly disordered [3,21].

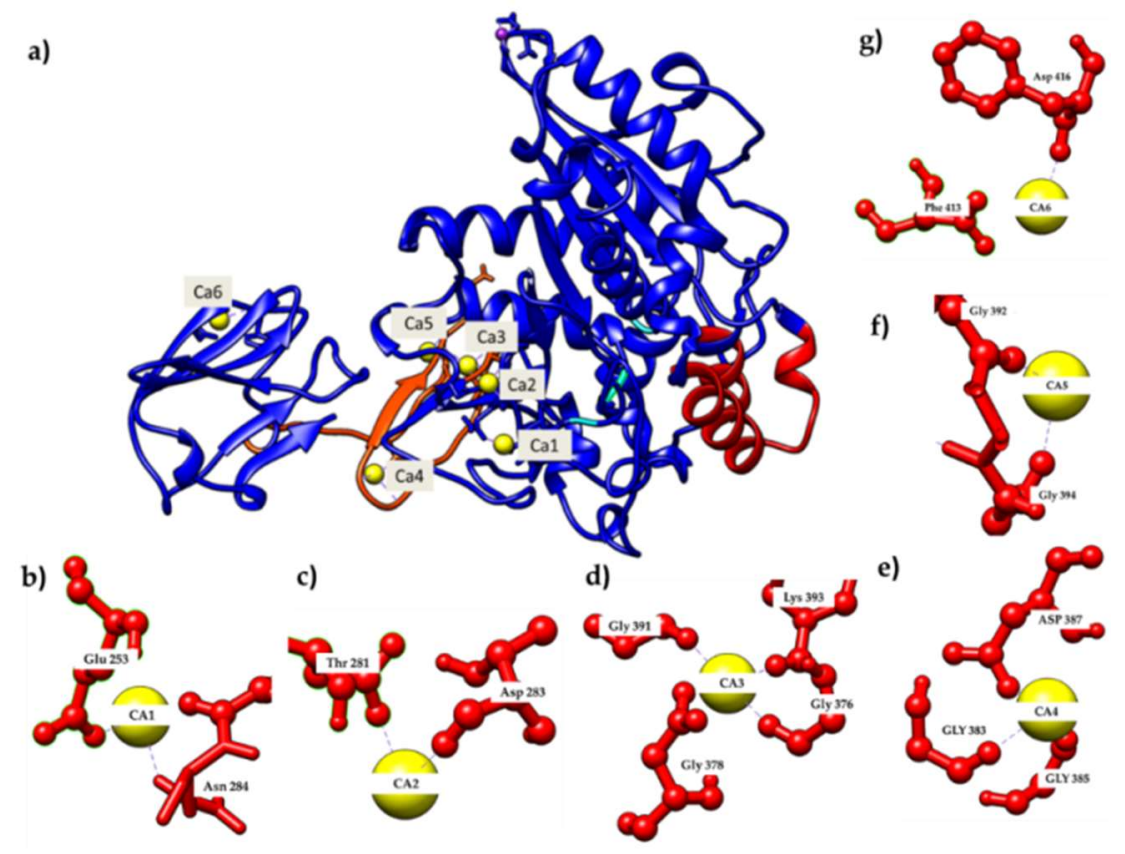

Figure 1. The predicted model of AMS8 lipase obtained from Ali et al. showed the presence of $\mathrm{Ca}^{2+}$ ions [7]. (a) Calcium-binding site of the AMS8 lipase predicted structure. (b) The Ca1 was bound with $\mathrm{Asn}^{284}$ and Glu ${ }^{253}$ residues, (c) Ca2 was bound with $\mathrm{Asp}^{283}$ and $\mathrm{Thr}^{281}$ residues, (d) Ca3 was bound with $\mathrm{Asp}^{378}$, Gly ${ }^{391}$, Lys ${ }^{393}$ and Gly ${ }^{376}$ residues, (e) Ca4 was bound with Asp ${ }^{387}$, Gly ${ }^{383}$ and Gly ${ }^{385}$ residues, (f) Ca5 was bound with $\mathrm{Gly}^{392}$ and Gly ${ }^{394}$ residues, and (g) Ca6 was bound with Phe ${ }^{413}$ and $\mathrm{Asp}^{416}$ residues. 
a)

$\begin{array}{lllllll}1 & \text { MGVFDYKNLG } & \text { TEGSKALFAD } & \text { AMATLYSYH } & \text { NLDNGFAVGY } & \text { OHNGFGLGL } & \text { ATLVGALLGS } \\ 61 & \text { TDSQGVIPGI } & \text { PWNPDSEKAA } & \text { LEAVNKAGWT } & \text { PISASTLGYG } & \text { GKVDARGTFF } & \text { GEKAGYTTAQ } \\ 121 & \text { VEVLGGYDGD } & \text { GKLLEGIGF } & \text { RGTSGPRETL } & \text { IIDSIGDLVS } & \text { DLLAALGPKD } & \text { YAKNYAGEAF } \\ 181 & \text { GTLLKDVAAY } & \text { AGSHGLTGKD } & \text { VVVSGHSLGG } & \text { LAVNSMADLS } & \text { GNKWSGFYKD } & \text { SNYVAYASPT } \\ 241 & \text { QSSGDKVLNI } & \text { GYENDPVFRA } & \text { LDGSSFNFSS } & \text { LGVHDKPHES } & \text { TTDNIVSFND } & \text { HYASTLWNVL } \\ 301 & \text { PFSIVNVPTW } & \text { LSHLPTGYGD } & \text { GLTRVLDSKF } & \text { YDLTSRDSTI } & \text { IVANLSDPAR } & \text { ANTWVQDLNR } \\ 361 & \text { NAEPHKGNTF } & \text { IIGDGNDLI } & \text { QGGKGVDFIE } & \text { GGKGNDTIRD } & \text { NSGHNIFLFG } & \text { GQFGQDRVIG } \\ 421 & \text { YQSTDKLVFK } & \text { DVEGSADWRD } & \text { HAKVVGGDTV } & \text { LSFGADSVTL } & \text { VGVGLAGVGG } & \text { DGISIS }\end{array}$

b)

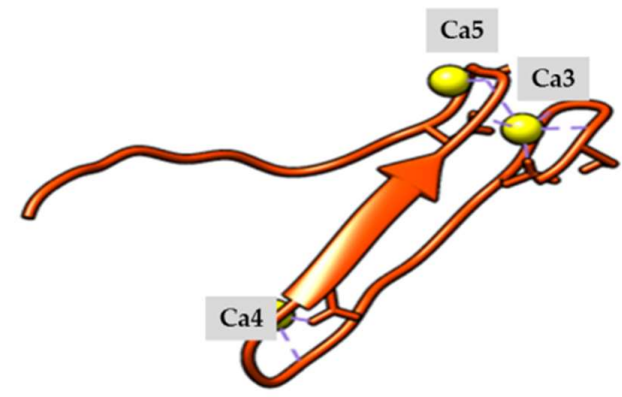

Figure 2. The repeat in toxin (RTX) parallel $\beta$-roll motif repeat structure of AMS8 lipase. (a) The AMS8 lipase sequence contains three RTX parallel $\beta$-roll motif repeat structures (GGXGXDXUX) at the C-terminal (residue 373-405) as highlighted in yellow. (b) Ca3, Ca4, and Ca5 were bound to the RTX parallel $\beta$-roll motif repeat structures.

\subsection{Effect of Different $\mathrm{Ca}^{2+}$ Ion Concentrations on AMS8 Lipase Activity}

The AMS8 lipase inclusion body (IB) was harvested from bacterial cultures through centrifugation. AMS8 lipase IBs were solubilized under denaturing conditions using urea to remove the $\mathrm{Ca}^{2+}$ ions. The previous study proved the workability of urea-based microbial carbonate precipitation as a $\mathrm{Ca}^{2+}$ ion removal technology [22]. Twelve different $\mathrm{CaCl}_{2}$ concentrations $(0,5,10,20,30,40,50,60,70,80$, 90 and $100 \mathrm{mM}$ ) had been used to optimize the best concentration of $\mathrm{CaCl}_{2}$ needed by the unfolded AMS8 lipase to correctly refold to its native structure.

A clear lysate was obtained during the refolding process without any protein precipitation as all the debris was removed during the solubilization process [6]. The refolded protein was assayed and analyzed to Sodium Dodecyl Sulfate-Polyacrylamide Gel Electrophoresis (SDS-PAGE) analysis. It was assumed that the AMS8 lipase had already been purified in the solubilization and refolding process since SDS-PAGE detected only the AMS8 lipase band. A single band of protein in the expected size $(65 \mathrm{kDa})$ was observed after the refolding process with different $\mathrm{CaCl}_{2}$ concentrations. The appearance of $\mathrm{CaCl}_{\mathrm{S}}$ had a significant influence on the lipase activity $(\mathrm{U} / \mathrm{mL})$ of AMS8 lipase. The effect of $\mathrm{Ca}^{2+}$ ions on refolded lipase activity is presented in Table 1 . The positive enzymatic activity by refolded AMS8 lipase indicates the successful refolding process since the protein was active.

Table 1. The refolded AMS8 lipase activity $(\mathrm{U} / \mathrm{mL})$ been analyzed with varying $\mathrm{CaCl}_{2}$ concentrations.

\begin{tabular}{cc}
\hline $\mathrm{CaCl}_{\mathbf{2}}$ Concentration $(\mathbf{m M})$ & Lipase Activity $\mathbf{( U / m L )}$ \\
\hline 0 & $26.40 \pm 0.74$ \\
5 & $137.99 \pm 7.70$ \\
10 & $157.08 \pm 1.81$ \\
20 & $160.00 \pm 3.69$ \\
30 & $169.23 \pm 2.92$ \\
40 & $173.88 \pm 2.98$ \\
50 & $183.67 \pm 0.93$ \\
60 & $198.48 \pm 1.58$ \\
70 & $218.23 \pm 0.25$ \\
80 & $262.49 \pm 3.91$ \\
90 & $255.18 \pm 1.74$ \\
100 & $226.69 \pm 1.32$ \\
\hline
\end{tabular}

The data are shown as the mean \pm S.D. (error bars) of the lipase activity $(\mathrm{U} / \mathrm{mL})$ of AMS8 lipase with different $\mathrm{CaCl}_{2}$ concentrations, performed in triplicate $(n=3)$. Significant statistical differences according to ANOVA $(p<0.05)$. 
Nevertheless, the total lipase activity depended on the concentration of $\mathrm{CaCl}_{2}$ used. With increasing $\mathrm{CaCl}_{2}$ concentrations $(5-70 \mathrm{mM})$, the lipase activity was progressively accelerated and reached the highest lipase activity in the presence of $80 \mathrm{mM} \mathrm{CaCl}_{2}$, in contrast to the negative control $(0 \mathrm{mM}) . \mathrm{CaCl}_{2}$ also improved the lipase activity from diverse microorganisms such as Bacillus subtilis 168, Bacillus thermoleovorans ID-1 andPseudomonas aeruginosa EF2. As previously published, higher concentrations of $\mathrm{CaCl}_{2}$ resulted in greater lipase activity of cold-adapted lipase from Pseudomonas fragi [23].

However, a further increase in $\mathrm{CaCl}_{2}$ concentration (90-100 mM) led to a decrease in the lipase activity since the value started to decrease from approximately 262.5 to $226.7 \mathrm{U} / \mathrm{mL}$. These conditions may be caused by the aggregation of the protein which will be discussed in dynamic light scattering (DLS) analysis. Based on the lipase activity results, it was proven that $\mathrm{CaCl}_{2}$ plays a vital function in the protein refolding process and catalytic activity. $80 \mathrm{mM} \mathrm{CaCl}_{2}$ was the optimum concentration needed for the refolding process of AMS8 lipase, in which the highest lipase activity had been detected.

\subsection{Circular Dichroism (CD) Analysis}

Circular dichroism measurements are tools generally used to measure a protein's secondary structure [24]. Figure 3 shows the far-UV CD spectra (observation range: 190-260 nm) of AMS8 lipase with different $\mathrm{CaCl}_{2}$ concentrations. Five different $\mathrm{CaCl}_{2}$ concentrations ( 0 (control), 20, 40, 60, 80 and $100 \mathrm{mM}$ ) were used to perform this analysis. Far-UV CD spectra revealed that the presence of $\mathrm{CaCl}_{2}$ improved the secondary structure of AMS8 lipase. The far-UV CD spectrum (Figure 3) gives a shift of the negative peak to approximately $218 \mathrm{~nm}$ and the presence of a positive peak at approximately $190 \mathrm{~nm}$ in the presence of $\mathrm{CaCl}_{2}$. This spectrum is indicative of an enhanced $\beta$-sheet secondary structure and is similar to the data published by Bauche et al. [25].

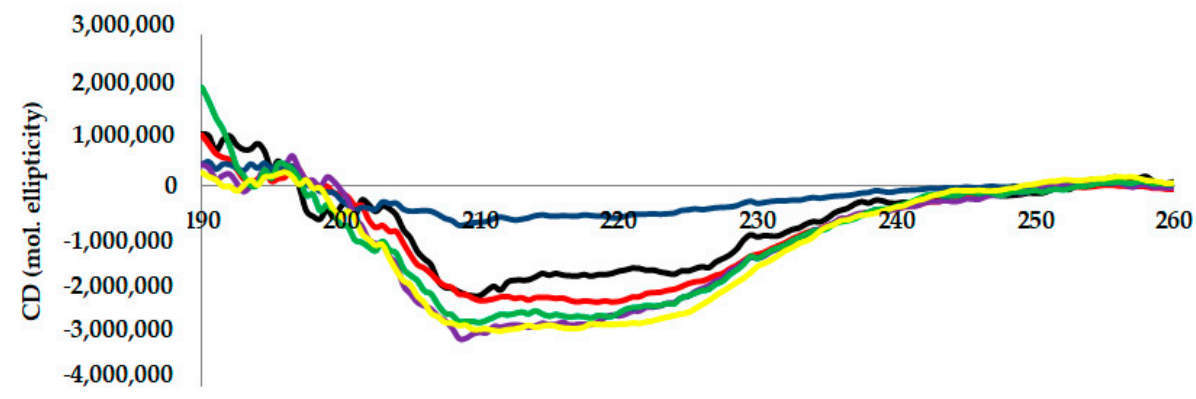

Wavelength (nm)

Figure 3. Far-UV CD spectra of AMS8 lipase in the presence of different $\mathrm{CaCl}_{2}$ concentrations $(0 \mathrm{mM}$ : black line, $20 \mathrm{mM}$ : red line, $40 \mathrm{mM}$ : blue line, $60 \mathrm{mM}$ : purple line, $80 \mathrm{mM}$ : green line and $100 \mathrm{mM}$ : yellow line). The protein concentrations and enzyme solutions were maintained at $1 \mathrm{mg} / \mathrm{mL}$ in $1 \mathrm{mM}$ Tris- $\mathrm{HCl}$ buffer in the presence of different $\mathrm{CaCl}_{2}$ concentrations.

The $\beta$-sheet data value increased in the presence of $\mathrm{CaCl}_{2}(20-60 \mathrm{mM})$. In a detailed observation, the percentage of $\beta$-sheet content obtained (20-60 mM) was not very different in three different $\mathrm{CaCl}_{2}$ concentrations. Nevertheless, the value started to decrease when higher $\mathrm{CaCl}_{2}$ concentrations were added $(90-100 \mathrm{mM})$. The decrease in lipase activity was caused by the decrease in $\beta$-sheet content, as shown in Table 2. This condition may be due to the aggregation of protein as reported by DLS analysis.

Based on the overall results, the presence of $80 \mathrm{mM} \mathrm{CaCl}_{2}$ gave the best secondary structure content, since the percentage of $\beta$-sheet and $\alpha$-helix was high compared to the other concentrations. Referring to the model built previously, the catalytic domain of AMS8 lipase was mainly built by an $\alpha / \beta$ fold and this domain is suggested to be a fundamental domain for the catalytic efficacy of AMS 8 lipase [6]. The helical structure of AMS8 is located inside the catalytic domain. Thus, this domain is proposed to be liable for the activity and stability of the protein despite the flexibility properties of the non-catalytic domain which represents a role in the structure and function of the protein [6]. 
Table 2. The changes in AMS8 lipase secondary structure contents analyzed with varying $\mathrm{CaCl}_{2}$ concentrations.

\begin{tabular}{ccccc}
\hline \multirow{2}{*}{\begin{tabular}{c}
$\mathbf{C a C l}_{2} \begin{array}{c}\text { Concentrations } \\
(\mathbf{m M})\end{array}$ \\
\cline { 2 - 5 }
\end{tabular}} & Beta & Helix & Turn & Random \\
\hline 0 & 7.7 & 25.3 & 30.7 & 36.5 \\
20 & 12.9 & 29.7 & 22.1 & 35.2 \\
40 & 22.1 & 19.4 & 21.7 & 36.8 \\
60 & 24.3 & 22.3 & 21.2 & 36.3 \\
80 & 26.7 & 21.2 & 19.9 & 32.2 \\
100 & 19.6 & 24.7 & 20.3 & 35.4 \\
\hline
\end{tabular}

\subsection{Fourier-Transform Infrared Spectroscopy (FTIR) Analysis}

FTIR spectroscopy is another biophysical tool that can also provide data about the secondary and tertiary structure content of the proteins by shining infrared radiation on a sample [26]. Interestingly, FTIR spectroscopy can also be used to analyze the calcium binding of protein [27]. Interaction of the protein with metal ions resulted in significant vibration and spectroscopy signals which was detected at wavelengths corresponding to three groups, namely, Amide A at $3500 \mathrm{~cm}^{-1}(\mathrm{NH})$, Amide I at $1700-1600 \mathrm{~cm}^{-1}(\mathrm{C}=\mathrm{O})$ and Amide II at $1550 \mathrm{~cm}^{-1}(\mathrm{C}-\mathrm{N}$ and $\mathrm{N}-\mathrm{H})$ [28]. Based on the FTIR analysis, two peaks were detected at the Amide 1 and Amide A wavelength. Both peaks present were sensitive to secondary structure content and metal ion interaction $\left(\mathrm{Ca}^{2+}\right.$ ion). For the interaction of $\mathrm{Ca}^{2+}$ ion binding, the Amide I peak (1700-1600 $\mathrm{cm}^{-1}$ ) and the Amide A peak (near $3500 \mathrm{~cm}^{-1}$ ) were slightly lower at low $\mathrm{Ca}^{2+}$ ion concentrations $(0-60 \mathrm{mM})$. However, the spectral intensity of the bands mentioned above was observed to increase significantly at a higher $\mathrm{Ca}^{2+}$ ion concentration $(80-100 \mathrm{mM})$. The increase in the spectral intensity was due to the reaction of the $\mathrm{Ca}^{2+}$ ion with the Amide I $(\mathrm{C}=\mathrm{O})$, Amide II $(\mathrm{C}-\mathrm{N}, \mathrm{N}-\mathrm{H})$ and Amide A $(\mathrm{NH})$ regions of the protein.

The FTIR spectrum was asymmetric, with a shoulder between 1600 and $1700 \mathrm{~cm}^{-1}$, proposing the appearance of absorption bands in this wavelength. The wave number of the maximum absorption of AMS8 lipase in the presence of $\mathrm{CaCl}_{2}$ was $1627 \mathrm{~cm}^{-1}$, which was assigned to $\beta$-sheet content. The Amide I wavelength precisely at $1621-1640 \mathrm{~cm}^{-1}$ represents $\beta$-sheet content (Figure 4). Based on the graph, the absorbance value shows the intensity of the stretching vibrations of the $\mathrm{C}=\mathrm{O}$ and $\mathrm{N}-\mathrm{H}$ bonds. From here, we can see the increment of $\beta$-sheet content in AMS8 lipase without the presence of $\mathrm{CaCl}_{2}$ $(0 \mathrm{mM})$ and with the presence of $\mathrm{CaCl}_{2}(20,40,60,80$ and $100 \mathrm{mM})$. AMS8 lipase with $80 \mathrm{mM} \mathrm{CaCl} 2$ gave the highest intensity compared to other concentrations used. FTIR analysis for the $\beta$-sheet content of AMS8 lipase was correlated to the CD analysis (Table 2). Both showed that the percentage of $\beta$-sheet content increased in the presence of $\mathrm{CaCl}_{2}$, and $80 \mathrm{mM}$ gave the highest $\beta$-sheet content. As with the $\mathrm{CD}$ analysis, the percentage of AMS8 lipase $\beta$-sheet content in the presence of $100 \mathrm{mM}$ decreased.
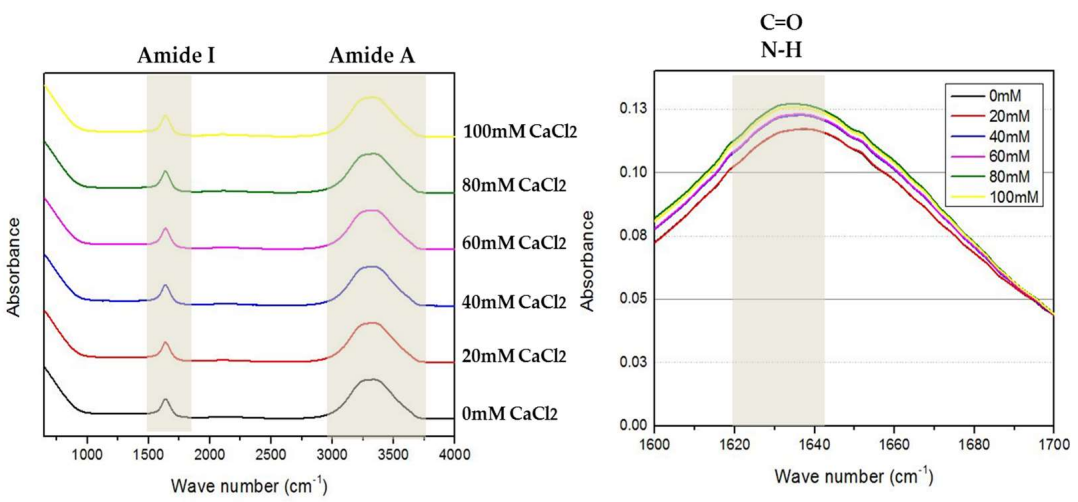

Figure 4. Fourier-transform infrared spectroscopy (FTIR) analysis in the presence of different $\mathrm{CaCl}_{2}$ concentrations ( $0 \mathrm{mM}$ : black line, $20 \mathrm{mM}$ : red line, $40 \mathrm{mM}$ : blue line, $60 \mathrm{mM}$ : purple line, $80 \mathrm{mM}$ : green line and $100 \mathrm{mM}$ : yellow line). The wavelength at $1600-1700 \mathrm{~cm}^{-1}$ represents Amide I and the wavelength at $1621-1640 \mathrm{~cm}^{-1}$ represents $\beta$-sheet content. The protein concentrations and enzyme solutions were maintained at $1 \mathrm{mg} / \mathrm{mL}$ in $1 \mathrm{mM}$ Tris- $\mathrm{HCl}$ buffer. 


\subsection{Fluorescence Spectroscopy Analysis}

AMS8 lipases contain seven Trp residues at positions 72, 89, 224, 297, 310, 354 and 438 (Figure 5). Figure 6 shows the folding/compactness analysis of AMS8 lipase with different $\mathrm{CaCl}_{2}$ tested using fluorescence spectroscopy (intrinsic and extrinsic ANS fluorescence). The fluorescence of lipases is due to aromatic residues (Trp, Tyr and Phe). Nevertheless, Trp residue is the most sensitive when exposed to fluorescence compared to Tyr and Phe residue. Intrinsic fluorescence parameters such as intensity and peak wavelength $\left(\lambda_{\max }\right)$ provide excellent means to study structural dynamics and lipase polarity [29]. The conformational changes in the fluorescence intensity of the AMS8 lipase with different $\mathrm{CaCl}_{2}$ concentrations reflect an alteration in the solvent accessibility and tertiary structure of aromatic residues.

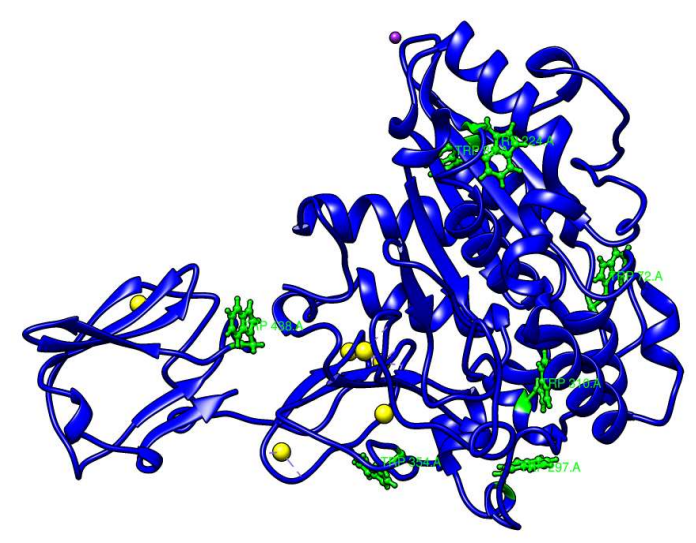

Figure 5. Distribution of tryptophan residues in the AMS8 lipase predicted structure. There are seven tryptophan residues at positions 72, 89, 224, 297, 310, 354 and 438 (green color).

As shown in Figure 6a, the AMS8 lipase without the addition of $\mathrm{CaCl}_{2}$ as a control $(0 \mathrm{mM})$ had maximum emission of $340 \mathrm{~nm}$, and the addition of different $\mathrm{CaCl}_{2}$ concentrations $(20,40,60,80$ and $100 \mathrm{mM}$ ) impact the fluorescence intensity. The fluorescence intensity of the AMS8 lipase increased slightly in the presence of $\mathrm{CaCl}_{2}$. AMS8 lipase was found to be blue shifted since the intensity decreased at $340 \mathrm{~nm}$. The blue shift in the $\lambda_{\max }$ present reflected the changes in the Trp microenvironment and its accessibility to an aqueous solution. It showed that the Trp was shielded from bulk water but not placed in the hydrophobic core of the lipases. Without the $\mathrm{CaCl}_{2}$, the $\lambda_{\max }$ decreased and reached a minimum value of $304 \mathrm{~nm}$. The structural propensity changes in the protein in response to $\mathrm{CaCl}_{2}$ indicate the involvement of specific intra-molecular interactions in the protein structure, which confers extra stability. In some ways, the appearance of metal ions may alter the electrostatics of the protein. The fluorescence of the protein is dependent on the environment and the folding of the protein. The more compact structure of the protein leads to a higher fluorescence intensity than the disordered/denatured counterpart [30]. Thus, the increased fluorescence intensity of AMS8 lipase in the presence of $\mathrm{Ca}^{2+}$ ion was reasonably contributing to the structural compactness of the protein in the aqueous medium.

The extrinsic ANS fluorescence further supported the effect of different $\mathrm{CaCl}_{2}$ concentrations. ANS binding upon the hydrophobic group of protein was also used for the detection of the formation of the molten globule state of the protein [31]. Extrinsic ANS fluorescence spectra of AMS8 lipases with $80 \mathrm{mM}$ of $\mathrm{CaCl}_{2}$ gave the highest intensity at $486 \mathrm{~nm}$ (Figure $6 \mathrm{~b}$ ). It shows the Trp residues were exposed to the environment/solvent. However, the AMS8 lipase peak emission intensity of another different $\mathrm{CaCl}_{2}$ concentration $(20,40,60$ and $100 \mathrm{mM})$ was significantly decreased. Therefore, the decrease in ANS fluorescence intensity was significantly linked to the reduced exposure (Trp buried inside the hydrophobic core) of Trp residue to the environment/solvent. 


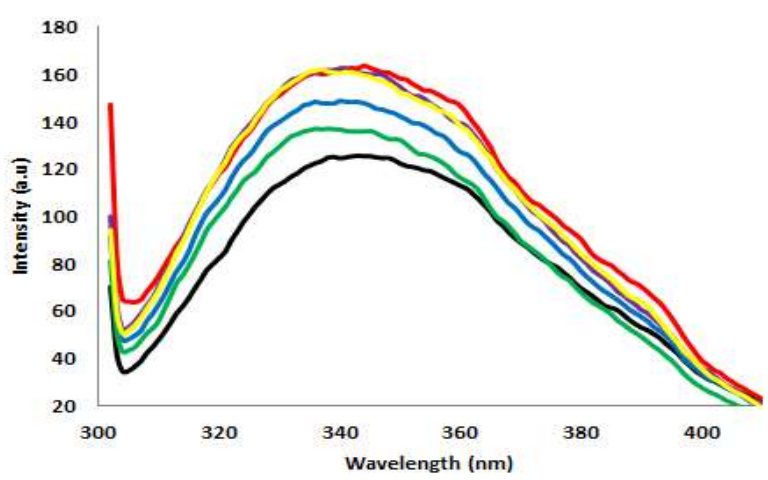

(a)

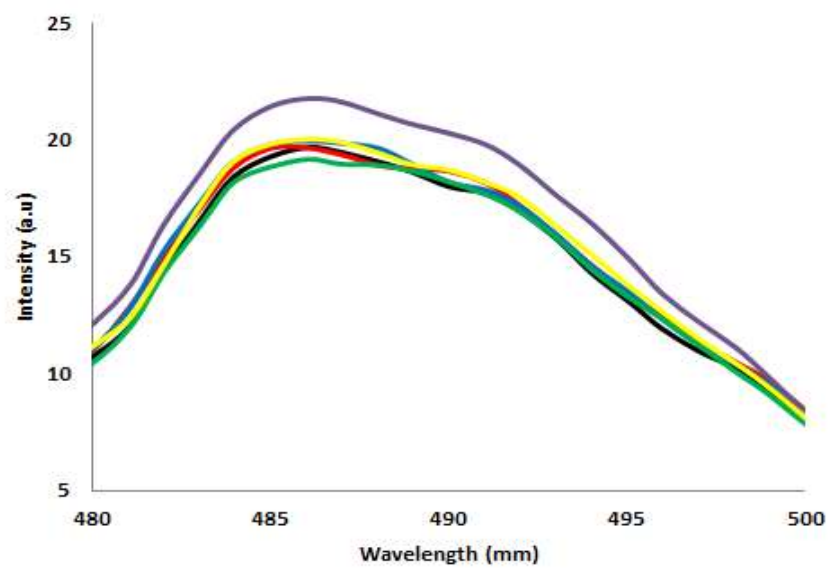

(b)

Figure 6. Fluorescence spectroscopy analysis. (a) Intrinsic fluorescent analysis of AMS8 lipase with different $\mathrm{CaCl}_{2}$ concentrations ( $0 \mathrm{mM}$ : black line, $20 \mathrm{mM}$ : red line, $40 \mathrm{mM}$ : blue line, $60 \mathrm{mM}$ : purple line, $80 \mathrm{mM}$ : green line and $100 \mathrm{mM}$ : yellow line). (b) Extrinsic fluorescent analysis of AMS8 lipase with different $\mathrm{CaCl}_{2}$ concentrations ( $0 \mathrm{mM}$ : black line, $20 \mathrm{mM}$ : red line, $40 \mathrm{mM}$ : blue line, $60 \mathrm{mM}$ : purple line, $80 \mathrm{mM}$ : green line and $100 \mathrm{mM}$ : yellow line).

\subsection{Dynamic Light Scattering (DLS) Analysis}

The DLS technique was applied to measure the size of the protein (other particles) by scattered light intensity. This method has recently been used in the study of folding and denaturation, aggregation, and also the complex formation of proteins in solution [24]. The DLS data was read based on the differences between the aggregation size of the sample and control. AMS8 lipase with various $\mathrm{CaCl}_{2}$ concentrations (20,40, 60, 80 and $100 \mathrm{mM}$ ) had been used as a sample and AMS8 lipase without being treated with $\mathrm{CaCl}_{2}(0 \mathrm{mM})$ had been used as a control.

Based on the result in Figure 7, increasing the $\mathrm{CaCl}_{2}$ concentration influenced the size of the protein. The average size of particles (in diameter) of 20, 40, 60, 80 and $100 \mathrm{mM} \mathrm{CaCl}_{2}$ was increased from 245.5 to $302.2,319.6,697.2,863.0$ and $1223 \mathrm{~nm}$ respectively. When the size of the protein was huge, the PI value would also be high because the sample was too polydispersed. Based on the quality report from the software, the sample might aggregate and contain large particles. This condition may lead to decreasing lipase activity at a higher concentration of $\mathrm{CaCl}_{2}$ as discussed in Section 2.2. 


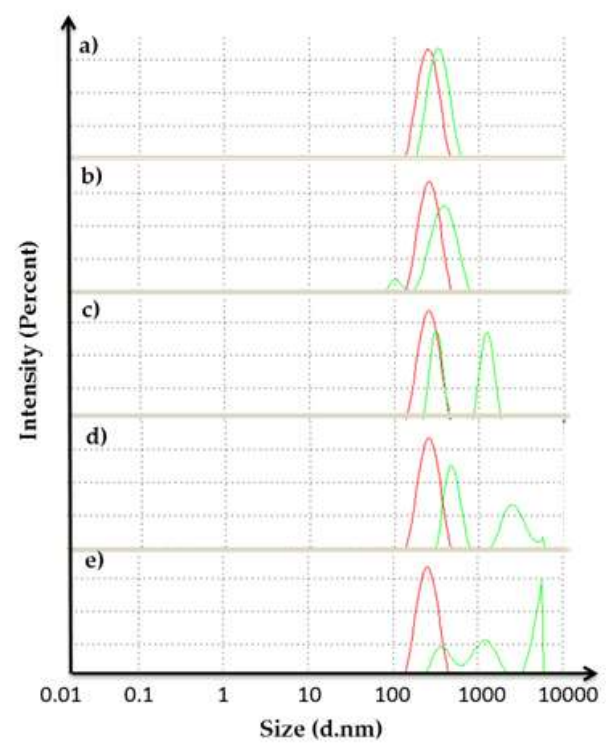

Figure 7. Dynamic light scattering (DLS) graph for the enhancement stage of the reaction (size in diameter (d.nm)). Concentration of $\mathrm{CaCl}_{2}$ in AMS8 lipase: (a) 20; (b) 40; (c) 60; (d) 80 and (e) 100 mM. The red curve represents the control and the green curve represents the sample.

\subsection{Isothermal Titration Calorimetry (ITC) Analysis}

In order to define the binding affinity of the AMS8 lipase with calcium, the enzyme-calcium interaction was observed using ITC. ITC was used to study all sorts of binding reactions, including protein-ligand reactions. ITC is the alternative method to calculate the thermodynamic parameters associated with the structural transformation of a single molecule or the non-covalent interaction of several molecules [32].

Representative calorimetric titrations of AMS8 lipase with $\mathrm{CaCl}_{2}$ were performed at $25{ }^{\circ} \mathrm{C}$. Injections were performed repeatedly and resulted in peaks that became smaller as the biomolecule became saturated after 25 injections (200s injection interval) had been performed. The normalized results are displayed under each titration result. The AMS8 lipase reaction with $\mathrm{CaCl}_{2}$ was exothermic, since a negative peak was observed. For this experiment, $5 \mu \mathrm{M}$ of AMS8 lipase and $50 \mu \mathrm{M}$ of $\mathrm{CaCl}_{2}$ were used. The concentration used was different from the other biophysical tools, since ITC only required a small amount of sample concentration. ITC was among the most sensitive biophysical tools that only required a small concentration of sample and ligand compared to other biophysical tools that had been used in this study.

Based on ITC analysis, we are focusing on the binding affinity between the protein and ligand. The binding affinity (dissociation constant $\left(\mathrm{K}_{\mathrm{d}}\right)$ ) was used to measure the strengths of biomolecular interactions. The $\mathrm{K}_{\mathrm{d}}$ value for AMS8 lipase with the ligand was $1.458 \times 10^{-7} \mathrm{M}$. Since the $\mathrm{K}_{\mathrm{d}}$ value observed was small, it proved that the $\mathrm{Ca}^{2+}$ ion was tightly bound to the AMS8 lipase. The lower the value of the $K_{d}$, the higher the ligand's binding affinity to AMS8 lipase. If the $K_{d}$ value was high, the ligand would be weakly bound to the protein (other target molecules) [33].

\section{Conclusions}

In conclusion, AMS8 lipase from Pseudomonas fluorescence belongs to the RTX lipases group since it contains an RTX parallel $\beta$-roll motif repeat structure at the C-terminal. This lipase contains three RTX parallel $\beta$-roll motif repeat structures and six $\mathrm{Ca}^{2+}$ ions. We have proven that in the presence of $\mathrm{Ca}^{2+}$ ions, the lipase activity of AMS8 lipase increased. This shows that the contribution of calcium binding performed a vital function in sustaining the structural integrity of AMS8 lipase. The evidence from lipase activity was further analyzed by using various biophysical characterizations. The biophysical characterization analyses (Far-UV CD spectra, FTIR spectroscopy, fluorescence spectroscopy, DLS 
and ITC) revealed that the presence of $\mathrm{Ca}^{2+}$ ions improved the secondary structure and made the folding of AMS8 lipase better compared to untreated AMS8 lipase (without $\mathrm{Ca}^{2+}$ ion). The result from various biophysical characterizations of the role of the calcium-induced activity/folding of RTX-containing lipase AMS8 may contribute fresh insights toward the calcium-binding relationship of the RTX lipases study.

\section{Materials and Methods}

\subsection{Calcium-Binding Site of AMS8 Lipase Predicted Model}

A previous study adopted a homology modelling approach to predict the AMS8 lipase structure [6]. The predicted 3D model (GenBank accession No: ADM87309.1) was obtained from Ali et al. [6] and was used in this research to analyze the calcium-binding site and RTX $\beta$-roll motif repeat structure. The ligplot of the interaction involving the calcium-binding site of AMS8 lipase was analyzed using the pictorial database of 3D structures in the Protein Data Bank (PDBsum) and visualized by using YASARA software [34].

\subsection{Expression, Solubilization and Refolding of AMS8 IBs with Different $\mathrm{Ca}^{2+}$ Ion Concentrations}

The expression of AMS8 lipase was conducted as mentioned by Jalil et al. with slight modifications [12]. The E. coli strain BL21(DE3) with recombinant plasmid pET32b/lipAMS8 was induced with IPTG $(0.1 \mathrm{mM})$ for AMS8 lipase production at $20^{\circ} \mathrm{C}$ with shaking at $180 \times \mathrm{g}$ for $18 \mathrm{~h}$. The production of AMS8 lipase was qualified by streaking the culture on an agar plate containing tributyrin $1 \%(v / v)$ and ampicillin $(50 \mu \mathrm{g} / \mathrm{mL})$. After three days of incubation at $4{ }^{\circ} \mathrm{C}$, the hydrolysis of tributyrin by a lipase was proven by the development of a halo zone (around colony) on the plate.

After the expression process, the pellet was collected and treated with $10 \mathrm{~mL}$ Tris- $\mathrm{HCl}$ buffer $(50 \mathrm{mM})$ containing urea $(8 \mathrm{M})$ at $\mathrm{pH} 8.0$ for solubilization for $3 \mathrm{~h}\left(4^{\circ} \mathrm{C}\right)$ with constant agitation. The solubilized AMS8 lipase was centrifuged for $30 \mathrm{~min}(10,000 \times g)$, and the supernatant containing IBs was refolded via a $10 \times$ dilution method by using the peristaltic pump with the slowest flow rate $(0.5 \mathrm{~mL} / \mathrm{min})$ against Tris- $\mathrm{HCl}(50 \mathrm{mM})$ at $\mathrm{pH} 8.0$ in various $\mathrm{CaCl}_{2}$ concentrations $(0,5,10,20,30,40,50$, $60,70,80,90$ and $100 \mathrm{mM}$ ). The refolded AMS8 lipase with different $\mathrm{CaCl}_{2}$ concentrations was assayed for lipase activity and protein content. Later, AMS8 lipase was used for SDS-PAGE and biophysical characterization analysis. The crude enzyme had been used as a positive control and AMS8 lipase without being treated with $\mathrm{CaCl}_{2}(0 \mathrm{mM})$ had been used as the negative control.

\subsection{Determination of Lipase Activity and Protein Content}

As stated by Kwon and Rhee, lipase activity was determined by the protocol [35]. The emulsion of olive oil (Bertoli, Italy) was made by the emulsification of olive oil and a buffer solution (Tris- $\mathrm{HCl}$, $\mathrm{pH}$ 8.0) (1:1 ratio). The reaction mixture comprising $250 \mathrm{~mL}$ of emulsion, $990 \mu \mathrm{L}$ Tris- $\mathrm{HCl}(\mathrm{pH} 8.0)$ buffer, $20 \mu \mathrm{L}$ of $\mathrm{CaCl}_{2}(20 \mathrm{mM})$ and $10 \mu \mathrm{L}$ enzymes was prepared before incubation for $30 \mathrm{~min}$ at $20^{\circ} \mathrm{C}$ with $180 \times g$ shaking. Afterward, $1 \mathrm{~mL}$ of $\mathrm{HCl}(6 \mathrm{~N})$ and by $5 \mathrm{~mL}$ of isooctane were combined to stop the reaction. The reaction mixtures were left for $30 \mathrm{~min}$ at $25^{\circ} \mathrm{C}$. Then, $1 \mathrm{~mL}$ copper pyridine solution ( $\mathrm{pH}$ 6.1) was mixed with the upper layer reaction. The absorbance $(715 \mathrm{~nm})$ of lipase activity was determined using a Biochrom WPA UV/visible spectrophotometer (Cambridge, UK). The protein concentration of AMS8 lipase was determined by Bradford assay [36] using the Bradford reagent (AMRESCO, Solon, OH, USA).

\subsection{Biophysical Characterizations}

\subsubsection{SDS-PAGE (Sodium Dodecyl Sulfate-Polyacrylamide Gel Electrophoresis) Analysis}

SDS-PAGE was conducted according to the method defined by Laemmli using $12 \%(w / v)$ of resolving gel and $4 \%(w / v)$ of stacking gels [37]. After the refolding process, the protein sample 
$(1 \mathrm{mg} / \mathrm{mL}$ ) was resuspended into 10× sample buffer (Tris-HCl (1 M, pH 6.8), 20\% (w/v) SDS and 1\% $(v / v)$ bromophenol blue). The protein samples $(10 \mu \mathrm{L})$ were electrophoresed on $40 \%$ acrylamide gel at $210 \mathrm{~V}, 60 \mathrm{~mA}$ for $50 \mathrm{~min}$ using a small electrophoresis chamber (Criterion Vertical Electrophoresis Cell, Bio-rad, Hercules, CA, USA). The gel was stained for $10 \mathrm{~min}$ with $0.25 \%$ Coomassie brilliant blue R 250 and destained overnight in destaining solution acetic acid:methanol:distilled water (ratio 1:1:8) [11]. The unstained protein marker (Fisher Scientific, Hampton, NH, USA) was used to estimate the molecular protein size.

\subsubsection{Circular Dichroism (CD) Spectra Analysis}

The secondary structure analysis of the AMS8 lipase was measured using JASCO 815 spectropolarimeter (JASCO, Tokyo, Japan). The secondary structure contents of AMS8 lipase with $\mathrm{CaCl}_{2}$ were valued based on the far-UV (190-260 nm) using a $1 \mathrm{~mm}$ path cell length at $20^{\circ} \mathrm{C}$. Refolded AMS8 lipase protein $\left(1 \mathrm{mg} / \mathrm{mL}\right.$ ) with varying $\mathrm{CaCl}_{2}$ concentrations (0 (control), 20, 40, 60, 80 and $100 \mathrm{mM}$ ) was prepared in Tris- $\mathrm{HCl}(1 \mathrm{mM}, \mathrm{pH} 8.0)$ buffer. The spectral analysis of AMS8 lipase was subtracted with the subsequent blank containing Tris- $\mathrm{HCl}(1 \mathrm{mM}, \mathrm{pH} 8.0)$. All measurements were repeated three times. The secondary structure contents (beta, helix, turn and random) of AMS8 lipase were analyzed using the method by Yang et al. [38], using Spectra Manager ${ }^{\mathrm{TM}}$ Suite Software (JASCO, Tokyo, Japan).

\subsubsection{Fourier-Transform Infrared (FTIR) Spectroscopy Analysis}

The FTIR spectroscopy analysis was completed using Cole-Parmer Scientific Experts (US). FTIR was measured in Tris- $\mathrm{HCl}$ buffer $(1 \mathrm{mM}, \mathrm{pH} 8.0)$ in the presence of various $\mathrm{CaCl}_{2}$ concentrations (0 (control), 20, 40, 60, 80 and $100 \mathrm{mM}$ ) at a spectral range of $4000-600 \mathrm{~cm}^{-1}$ with a nominal resolution of $2 \mathrm{~cm}^{-1}$ of 100 scans.

\subsubsection{Fluorescence Spectra Analysis}

The intrinsic fluorescence spectra of the protein were measured by a Cary Eclipse Fluorescence Spectrophotometer (Agilent, Santa Clara, CA, USA) using a quartz fluorimeter cuvette (100 $\mathrm{mm}$ light path, $1.4 \mathrm{~mL})$ at $25^{\circ} \mathrm{C}$. The protein sample $(1 \mathrm{mg} / \mathrm{mL})$ was tested at various $\mathrm{CaCl}_{2}$ concentrations (0 (control), 20, 40, 60, 80 and $100 \mathrm{mM}$ ). The excitation wavelength was $290 \mathrm{~nm}$, and the emission was scanned at 300 to $400 \mathrm{~nm}$. Binding of 8-anilino-1-naphthalenesulfonic acid (ANS) to the protein was analyzed by measuring the fluorescence of ANS at $25^{\circ} \mathrm{C}$. The protein sample $(1 \mathrm{mg} / \mathrm{mL})$ and ANS $(50 \mu \mathrm{M})$ were dissolved in Tris- $\mathrm{HCl}$ buffer $(80 \mathrm{mM}, \mathrm{pH} 8.0)$. The mixture was tested at various $\mathrm{CaCl}_{2}$ concentrations ( 0 (control), 20, 40, 60, 80, and $100 \mathrm{mM}$ ). The protein sample with ANS was scanned at a wavelength of $380 \mathrm{~nm}$ for excitation and 390 to $650 \mathrm{~nm}$ for emission.

\subsubsection{Dynamic Light Scattering (DLS) Analysis}

The measurement of protein particle size in refolded AMS8 lipase with different $\mathrm{CaCl}_{2}$ concentrations was carried out using a Zetasizer APS DLS machine (Malvern Panalytical, Malvern, UK) at $830 \mathrm{~nm}$ and the results were analyzed using Zetasizer software [39]. The protein samples $\left(1 \mathrm{mg} / \mathrm{mL}\right.$ ) were tested at various $\mathrm{CaCl}_{2}$ concentrations ( 0 (control), 20, 40, 60, 80 and $100 \mathrm{mM}$ ) and were used for DLS evaluation. The total volume of $150 \mu \mathrm{L}$ of the mixture was transferred into 96-well microplates before injecting into the DLS. The DLS system was set to a temperature of $25^{\circ} \mathrm{C}$, with Tris- $\mathrm{HCl}$ as a buffer and latex as a standard sample throughout the analysis. The result was set to be in normal resolution.

\subsubsection{Isothermal Titration Calorimetry (ITC) Analysis}

The protein-ligand measurements were performed using a Nano ITC, TA Instrument (US). The cell contained $300 \mu \mathrm{L}$ of degassed AMS8 lipase $(5 \mu \mathrm{M})$ with Tris- $\mathrm{HCl}(1 \mathrm{mM}, \mathrm{pH} 8.0)$ buffer was titrated 
with Tris- $\mathrm{HCl}\left(1 \mathrm{mM}, \mathrm{pH}\right.$ 8.0) buffer containing $\mathrm{CaCl}_{2}(50 \mu \mathrm{M})$. Ligand solutions $\left(50 \mu \mathrm{M} \mathrm{CaCl}_{2}\right)$ were injected until there were no more heat changes. Titrations of the Tris- $\mathrm{HCl}(1 \mathrm{mM}, \mathrm{pH} 8.0)$ buffer with the $\mathrm{CaCl}_{2}(50 \mu \mathrm{M})$ were performed with the same parameters as mentioned above, and these reference data were deducted from the standard. NanoAnalyzer software was used to analyze ITC data.

Supplementary Materials: The following are available online at http://www.mdpi.com/2072-6651/12/1/27/s1, Figure S1: The predicted structure of AMS8 lipase obtained from Ali et al. (2013).

Author Contributions: Conceptualization, N.S.M.A. and M.S.M.A.; Data curation, N.S.M.A.; Formal analysis, N.S.M.A. and M.S.M.A.; Funding acquisition, A.B.S.; Methodology, N.S.M.A. and M.S.M.A.; Project administration, M.S.M.A.; Resources, R.N.Z.R.A.R.; Supervision, M.S.M.A.; Writing-original draft, N.S.M.A.; Writing-review and editing, A.B.S., R.N.Z.R.A.R., T.C.L. and M.S.M.A. All authors have read and agreed to the published version of the manuscript.

Funding: Putra Grant funded this research, grant number 9551100, and N.S.M.A. was sponsored by a Graduate Research Fellowship (GRF).

Acknowledgments: The authors thank Muhammad Faizan A. Shukor from Universiti Pertahanan Nasional Malaysia (UPNM) for FTIR analysis and Azyyati Mohd Padzil from Malaysia Genome Institute (MGI) for CD spectra, Fluorescence spectra and ITC analysis.

Conflicts of Interest: The authors declare no conflict of interest.

\section{References}

1. Linhartova, I.; Bumba, L.; Masin, J.; Basler, M.; Osicka, R.; Kamanova, J.; Prochazkova, K.; Adkins, I.; Hejnova-Holubova, J.; Sadilkova, L.; et al. RTX Proteins: A Highly Diverse Family Secreted by a Common Mechanism. FEMS Microbiol. Rev. 2010, 34, 1076-1112. [CrossRef]

2. Sotomayor-Perez, A.C.; Ladant, D.; Chenal, A. Calcium-Induced Folding of Intrinsically Disordered Repeat-in-Toxin (RTX) Motifs via Changes of Protein Charges and Oligomerization States. J. Biol. Chem. 2011, 286, 16997-17004. [CrossRef] [PubMed]

3. Chenal, A.; Guijarro, J.I.; Raynal, B.; Delepierre, M.; Ladant, D. RTX Calcium Binding Motifs Are Intrinsically Disordered in the Absence of Calcium: Implication for Protein Secretion. J. Biol. Chem. 2009, 284, 1781-1789. [CrossRef] [PubMed]

4. Lilie, H.; Haehnel, W.; Rudolph, R.; Baumann, U. Folding of a Synthetic Parallel $\beta$-Roll Protein. FEBS Lett. 2000, 470, 173-177. [CrossRef]

5. Zhang, L.; Conway, J.F.; Thibodeau, P.H. Calcium-Induced Folding and Stabilization of the Pseudomonas Aeruginosa Alkaline Protease. J. Biol. Chem. 2012, 287, 4311-4322. [CrossRef] [PubMed]

6. Ali, M.S.M.; Ganasen, M.; Rahman, R.N.Z.R.A.; Chor, A.L.T.; Salleh, A.B.; Basri, M. Cold-Adapted RTX Lipase from Antarctic Pseudomonas sp. Strain AMS8: Isolation, Molecular Modeling and Heterologous Expression. Protein J. 2013, 32, 317-325. [CrossRef]

7. Ali, M.S.M.; Fuzi, S.F.M.; Ganasen, M.; Rahman, R.N.Z.R.A.; Basri, M.; Salleh, A.B. Structural Adaptation of Cold-Active RTX Lipase from Pseudomonas sp. Strain AMS8 Revealed via Homology and Molecular Dynamics Simulation Approaches. BioMed Res. Int. 2013, 2013, 925373. [CrossRef]

8. Yaacob, N.; Mohamad Ali, M.S.; Salleh, A.B.; Rahman, R.N.Z.R.A.; Leow, A.T.C. Toluene Promotes Lid 2 Interfacial Activation of Cold Active Solvent Tolerant Lipase from Pseudomonas Fluorescens Strain AMS8. J. Mol. Graph. Model. 2016, 68, 224-235. [CrossRef]

9. Short, E.C.; Kurtz, H.J. Properties of the Hemolytic Activities of Escherichia coli. Infect. Immun. 1971, 3, 678-687.

10. Stigler, J.; Ziegler, F.; Gieseke, A.; Gebhardt, J.C.M.; Rief, M. The Complex Folding Network of Single Calmodulin Molecules. Science 2011, 334, 512-516. [CrossRef]

11. Ganasen, M.; Yaacob, N.; Rahman, R.N.Z.R.A.; Leow, A.T.C.; Basri, M.; Salleh, A.B.; Ali, M.S.M. Cold-Adapted Organic Solvent Tolerant Alkalophilic Family I.3 Lipase from an Antarctic Pseudomonas. Int. J. Biol. Macromol. 2016, 92, 1266-1276. [CrossRef] [PubMed]

12. Abd. Jalil, F.; Raja Abd. Rahman, R.; Salleh, A.; Mohamad Ali, M. Optimization and in Silico Analysis of a Cold-Adapted Lipase from an Antarctic Pseudomonas sp. Strain AMS8 Reaction in Triton X-100 Reverse Micelles. Catalysts 2018, 8, 289. [CrossRef] 
13. Farfel, Z.; Friedman, E.; Hanski, E. The Invasive Adenylate Cyclase of Bordetella Pertussis. Intracellular Localization and Kinetics of Penetration into Various Cells. Biochem. J. 1987, 243, 153-158. [CrossRef] [PubMed]

14. Gangola, P.; RosenS, B.P. Maintenance of Intracellular Calcium in Escherichia coli. J. Biol. Chem. 1987, 262, 12570-12574.

15. Kenny, B.; Haigh, R. Analysis of the haemolysin transport process through the secretion from Escherichia coli of PCM, CAT or $\beta$-galactosidase fused to the Hly C-terminal signal domain. Mol. Microbiol. 1991, 5, 2557-2568. [CrossRef]

16. Koronakis, E.; Hughes, C.; Milisav, I.; Koronakis, V. Protein exporter function and in vitro ATPase activity are correlated in ABC-domain mutants of HlyB. Mol. Microbiol. 1995, 16, 87-96. [CrossRef]

17. Felmlee, T.; Welch, R.A. Alterations of Amino Acid Repeats in the Escherichia Coli Hemolysin Affect Cytolytic Activity and Secretion. Proc. Natl. Acad. Sci. USA 1988, 85, 5269-5273. [CrossRef]

18. Rhodes, C.R.; Gray, M.C.; Watson, J.M.; Muratore, T.L.; Kim, S.B.; Hewlett, E.L.; Grisham, C.M. Structural Consequences of Divalent Metal Binding by the Adenylyl Cyclase Toxin of Bordetella pertussis. Arch. Biochem. Biophys. 2001, 395, 169-176. [CrossRef]

19. Rose, T.; Sebo, P.; Bellalou, J.; Ladant, D. Characterization of Multiple Calcium-Binding Sites and Calcium-Induced Conformational Changes. J. Biol. Chem. 1995, 44, 26370-26376. [CrossRef]

20. Bindreither, D.; Lackner, P. Structural Diversity of Calcium Binding Sites. Gen. Physiol. Biophys. 2009, 28, $82-88$.

21. O’Brien, D.P.; Perez, A.C.S.; Karst, J.; Cannella, S.E.; Enguéné, V.Y.N.; Hessel, A.; Raoux-Barbot, D.; Voegele, A.; Subrini, O.; Davi, M.; et al. Calcium-Dependent Disorder-to-Order Transitions Are Central to the Secretion and Folding of the CyaA Toxin of Bordetella Pertussis, the Causative Agent of Whooping Cough. Toxicon 2018, 149, 37-44. [CrossRef] [PubMed]

22. Isik, M.; Altas, L.; Ozcan, S.; Simsek, I.; Agdag, O.N.; Alas, A. Effect of Urea Concentration on Microbial Ca Precipitation. J. Ind. Eng. Chem. 2012, 18, 1908-1911. [CrossRef]

23. Alquati, C.; De Gioia, L.; Santarossa, G.; Alberghina, L.; Fantucci, P.; Lotti, M. The Cold-Active Lipase of Pseudomonas Fragi: Heterologous Expression, Biochemical Characterization and Molecular Modeling. Eur. J. Biochem. 2002, 269, 3321-3328. [CrossRef] [PubMed]

24. Takeuchi, K.; Nakatani, Y.; Hisatomi, O. Accuracy of Protein Size Estimates Based on Light Scattering Measurements. Open J. Biophys. 2014, 4, 83-91. [CrossRef]

25. Bauche, C.; Chenal, A.; Knapp, O.; Bodenreider, C.; Benz, R.; Chaffotte, A.; Ladant, D. Structural and Functional Characterization of an Essential RTX Subdomain of Bordetella Pertussis Adenylate Cyclase Toxin. J. Biol. Chem. 2006, 281, 16914-16926. [CrossRef] [PubMed]

26. Gallagher, W. FTIR Analysis of Protein Structure. Course Man. Chem. 2009, 455, 1-8.

27. Fabian, H.; Vogel, H.J. Fourier Transform Infrared Spectroscopy of Calcium-Binding Proteins. In Calcium-Binding Protein Protocols; Humana Press: Totowa, NJ, USA, 2002; Volume 173, pp. 57-74. [CrossRef]

28. Alhazmi, H.A. FT-IR Spectroscopy for the Identification of Binding Sites and Measurements of the Binding Interactions of Important Metal Ions with Bovine Serum Albumin. Sci. Pharm. 2019, 87, 1-5. [CrossRef]

29. Kwaambwa, H.M.; Maikokera, R. A Fluorescence Spectroscopic Study of a Coagulating Protein Extracted from Moringa Oleifera Seeds. Colloids Surf. B Biointerfaces 2007, 60, 213-220. [CrossRef]

30. Das, S.; Pal, U.; Chandra Maiti, N. Metal Ions Provide Structural Stability and Compactness to Tetrameric Purothionin. RSC Adv. 2016, 6, 90690-90700. [CrossRef]

31. Singh, N.; Kumar, R.; Jagannadham, M.V.; Kayastha, A.M. Evidence for a Molten Globule State in Cicer $\alpha$-Galactosidase Induced by PH, Temperature, and Guanidine Hydrochloride. Appl. Biochem. Biotechnol. 2013, 169, 2315-2325. [CrossRef]

32. Falconer, R.J. Applications of Isothermal Titration Calorimetry-The Research and Technical Developments from 2011 to 2015: Review of Isothermal Titration Calorimetry from 2011 to 2015. J. Mol. Recognit. 2016, 29, 504-515. [CrossRef] [PubMed]

33. Radhakrishnan, A.; Stein, A.; Jahn, R.; Fasshauer, D. The $\mathrm{Ca}^{2+}$ affinity of synaptotagmin 1 is markedly increased by a specific interaction of its C2B domain with phosphatidylinositol 4,5-bisphosphate. J. Biol. Chem. 2009, 284, 25749-25760. [CrossRef] [PubMed]

34. Krieger, E.; Koraimann, G.; Vriend, G. Increasing the Precision of Comparative Models with YASARA NOVA-a Self-Parameterizing Force Field. Proteins 2002, 47, 393-402. [CrossRef] [PubMed] 
35. Kwon, D.Y.; Rhee, J.S. A Simple and Rapid Colorimetric Method for Determination of Free Fatty Acids for Lipase Assay. J. Am. Oil Chem. 1986, 63, 89-92. [CrossRef]

36. Bradford, M.M. A Rapid and Sensitive Method for the Quantitation of Microgram Quantities of Protein Utilizing the Principle of Protein-Dye Binding. Anal. Biochem. 1976, 72, 248-254. [CrossRef]

37. Laemmli, U.K. Cleavage of Structural Proteins during the Assembly of the Head of Bacteriophage T4. Nature 1970, 227, 680-685. [CrossRef]

38. Yang, J.T.; Wu, C.-S.C.; Martinez, H.M. [11] Calculation of Protein Conformation from Circular Dichroism. In Methods in Enzymology; Elsevier: Amsterdam, The Netherlands, 1986; Volume 130, pp. 208-269. [CrossRef]

39. Hall, H. Malvern Zetasizer Nano Basic Operating Instructions; Iowa State University: Ames, IA, USA, 2015.

(C) 2020 by the authors. Licensee MDPI, Basel, Switzerland. This article is an open access article distributed under the terms and conditions of the Creative Commons Attribution (CC BY) license (http://creativecommons.org/licenses/by/4.0/). 